\title{
EVALUATION OF FATIGUE BEHAVIOR ON ENGINE COMPONENT MADE OF AUSTEMPERED DUCTILE IRON
}

\author{
Laura Elisa Bollini $^{1}$, Almir Atoatte ${ }^{1}$ \\ ${ }^{1}$ ThyssenKrupp Metalúrgica Campo Limpo Ltda. \\ E-mails: 1aura.bollini@thyssenkrupp.com, almir.atoatte@thyssenkrupp.com
}

\begin{abstract}
Austempered Ductile Iron (ADI) is a nodular cast iron, thermally treated by the austempering process, which results in superior mechanical properties such as tenacity, ductility, wear and fatigue resistance, broadening the application field of cast irons and becoming a high competitive engineering material. In this paper, some concepts about fatigue limits on ADI parts and their experimental validation through fatigue experiments are presented. These experiments were performed on two different connecting rods with the same geometric characteristics but obtained by two different processes. The conclusion was that microstructure characteristics of the matrix and graphite nodules and also the porosity are great influences on the fatigue behavior of this material applied to connecting rods.
\end{abstract}

\section{INTRODUCTION}

The automotive industry, especially engine, is suffering several evolutions throughout the years to attend regulations. One of the most important regulations for diesel vehicles applications, EURO V, is in force in Brazil since 2012 and aims the reduction of pollutants. In numbers, the reduction must be around $88 \%$ of $\mathrm{CO}$ and $87 \%$ of NOx, compared to EURO 0 vehicles [1]. Reductions on weight, friction losses and fuel consumption are necessary to accomplish the emission and efficiency targets, thus engine components manufacturers need to adapt their products and processes and introduce new technologies in the market. This way, the engines can be smaller, more efficient and, consequently, more competitive.

Connecting rods are one of the most important components for engine operation, because they transform the linear movement of the piston, driven by the explosion, into rotational movement of the crankshaft. They are smaller than other components and already have an optimized geometry; therefore a good alternative for connecting rods to attend the main drivers of current market and regulations is material modification. Nowadays, connecting rods for heavy diesel engines, are made of steel and are obtained by forging, which gives them great ductility, machinability, fatigue resistance and mechanical strength.

Smaller connecting rods, are already made from other processes such as sinter-forging or casting, but their specifications are far below from diesel engine requirements and forged steel still provide the best properties combination for heavy engines. It is known that, austempered nodular cast iron (ADI) can provide some mechanical properties comparable to forged steel and can become a competitive material for engine components, specially because of its lower 
weight and higher friction resistance. This paper has the objective to investigate the fatigue behavior, microstructure characteristics and mechanical properties of ADI connecting rods casted by two different foundries and compare them to forged steel connecting rod already available on the market.

\section{LITERATURE REVIEW}

Austempered ductile iron, known as ADI, is a nodular cast iron with some alloy elements and thermally treated by the austempering process. It is being largely used on mining, rail and applications that involve great abrasive wear and high mechanical stresses [2]. The austempering process is an isothermal heat treatment and is divided in five phases as shown in Figure 1 and explained below.

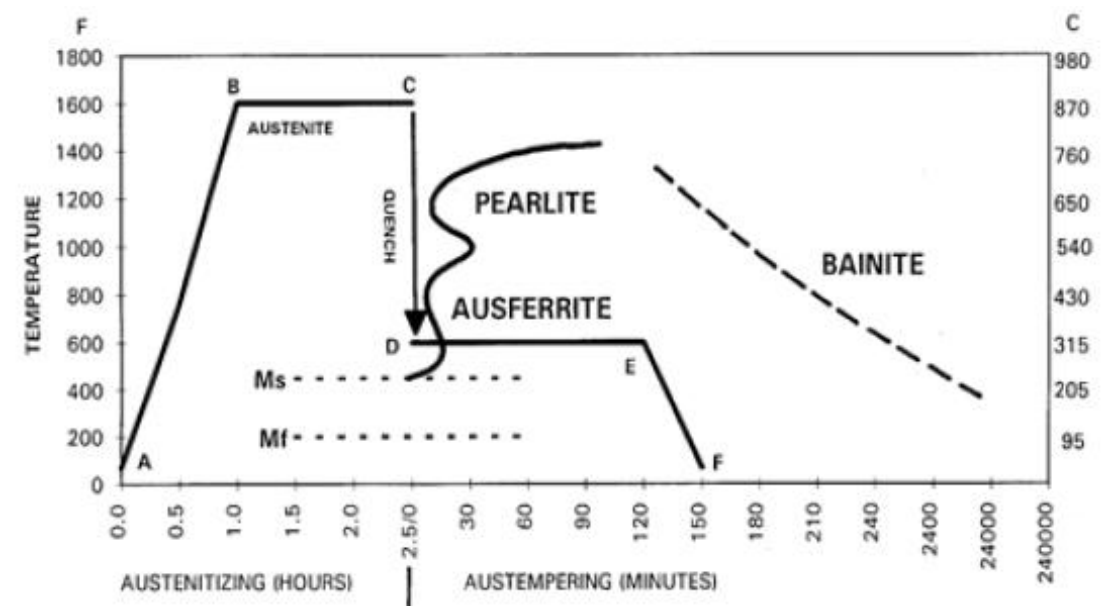

Figure 1: Typical austempering process [3]

Phase $1(\mathrm{~A}-\mathrm{B})$ is the heating process, where the temperature is elevated until a range from $840^{\circ} \mathrm{C}$ to $950^{\circ} \mathrm{C}$. Phase 2 (B-C) is the austenitizing process in which the temperature is kept for 1 to 3 hours until all matrix is transformed into austenite saturated with carbon. Phase 3 (C-D) is quenching process where the part is rapidly cooled down to the austempering temperature. Phase 4 (D-E) is the austempering process where the austenitic matrix begins to transform into ausferrite. Ausferrite is a mixture of stable austenite with dispersed acicular ferrite and this is the microstructure that gives ADI its special features. Phase 5 (E-F) is the final cooling stage until room temperature, avoiding the bainite formation region [3].

Compared to common nodular cast irons, ADI has five times more ductility, better vibration damper capacity and produce less noise during operation. Compared to forged steels, ADI has $10 \%$ less density, more design and manufacturing flexibility and higher tensile strengths, but $20 \%$ less elasticity. Most of ADI problems lie on process control due to the lack of understanding of the microstructure kinetics and the full dependency of mechanical properties on the heat treatment $[4,5]$.

To achieve ideal ADI microstructure with right amount of ausferrite and expected properties, temperature of the heat treatment must be controlled. Higher austempering temperatures improve impact strength due to bigger size of acicular ferrites, but ductility is compromised. On the other hand, low austempering temperatures coarse the microstructure improving mechanical and wear resistance [6]. The austempering time is even more important on heat treatment; it must be long enough to stabilize the austenite and form acicular ferrite but not 
long enough to form bainitic structure. This time varies according to the temperature and chemical composition and is called "process window" and other authors $[4,7]$ already tried to establish the optimal timing for austempering.

Additional care must be taken regarding the alloy elements. Recommended chemical composition for production of austempered ductile iron must contain silicon, manganese, copper, nickel and molybdenum. Silicon and magnesium improve graphite formation and nodularization while manganese accelerates the carbon solubility and diffusion to the austenite, but high levels of these elements can be deleterious due to their segregation around graphite nodules and carbide formation [5]. Copper and nickel delay the pearlite formation and suppress carbide formation but their use is restricted due to high costs.

Due to the variation of different parameters on the process to obtain ADI, ASTM classified the resulting austempered ductile iron types into six categories, as shown in Table 1 below, according to the properties achieved.

Table 1: ADI Grades and Properties [8]

\begin{tabular}{c|ccccc}
\hline Grade & $\begin{array}{c}\text { UTS } \\
(\boldsymbol{M P a})\end{array}$ & $\begin{array}{c}\boldsymbol{Y S} \\
(\boldsymbol{M P a})\end{array}$ & $\begin{array}{c}\text { Elongation } \\
(\boldsymbol{\%})\end{array}$ & $\begin{array}{c}\text { Impact } \\
(\boldsymbol{J})\end{array}$ & $\begin{array}{c}\text { Hardness } \\
(\boldsymbol{H B})\end{array}$ \\
\hline $\mathbf{7 5 0 / 5 0 0 / 1 1}$ & 750 & 500 & 11 & 110 & $241-302$ \\
$\mathbf{9 0 0 / 6 5 0 / 0 9}$ & 900 & 650 & 9 & 100 & $269-341$ \\
$\mathbf{1 0 5 0 / 7 5 0 / 0 7}$ & 1050 & 750 & 7 & 80 & $302-375$ \\
$\mathbf{1 2 0 0 / 8 5 0 / 0 4}$ & 1200 & 850 & 4 & 60 & $341-444$ \\
$\mathbf{1 4 0 0 / 1 1 0 0 / 0 2}$ & 1400 & 1100 & 2 & 35 & $388-477$ \\
$\mathbf{1 6 0 0 / 1 3 0 0 / 0 1}$ & 1600 & 1300 & 1 & 20 & $402-512$ \\
\hline
\end{tabular}

Regarding fatigue strength, the maximum values registered on literature [6] are related to the intermediary values of tensile strength, between 1050 and $1200 \mathrm{MPa}$. Some microstructure features like nodule count between 100 and 200 nodules $/ \mathrm{mm}^{2}$, nodules with high nodularity ( $>90 \%$ ), high volume of stable austenite and use of additional processes, such as shot peening can enhance fatigue behavior of the component [6]. It is also known that limits on ADI are strongly dependent on the presence of defects arising from casting, such as shrinkage or porosity. It is recommended that the maximum shrinkage volume is $1 \%$ [9].

The major limitations of ADI lie on machining, which is more difficult due to the higher hardening rates of austenite and high values of hardness achieved on the austempering process. Also, during machining, metastable austenite easily transforms into martensite reducing even more shock and thermal fatigue resistance of the ADI component and improving the superficial hardness [10]. Other factors need to be considered before the machining step such as thermal expansion and distortion, which impact directly on the machining tolerances.

These problems can be solved by a dimension prediction on the design phase [11] or by rough machining. ADI parts can be machined rather easily when done prior to the austempering process which adds to manufacturability of this material [11] and finish machined to accommodate design tolerances. It is clear that machining ADI is very difficult and the appropriate tools need to have high toughness, thermal conductibility and wear resistance. 


\section{EXPERIMENTAL PROCEDURE}

\subsection{Material}

To determine the chemical composition and heat treatment parameters before connecting rod application, tests using Y blocks were performed. Y blocks were manufactured according to ASTM [8] geometry specifications and had chemical composition presented on table 2, inside the ASTM [8] range. Also, it was stablished, based on the same standard, that the final casted iron must contain a nodule count of, at least, 100 nodules $/ \mathrm{mm}^{2}$ with minimum $80 \%$ of nodulatization.

Table 2: Chemical composition

\begin{tabular}{l|lllllllll}
\hline [\%] & $\boldsymbol{C}$ & $\boldsymbol{S i}$ & $\boldsymbol{M n}$ & $\boldsymbol{P}$ & $\boldsymbol{S}$ & $\boldsymbol{C u}$ & $\boldsymbol{C r}$ & $\boldsymbol{S n}$ & $\boldsymbol{M g}$ \\
\hline Maximum & 3,60 & 2,50 & 0,30 & 0,05 & 0,02 & 0,75 & 0,02 & 0,02 & 0,04 \\
Minimum & 3,40 & 2,20 & 0,20 & 0,00 & 0,00 & 0,70 & 0,00 & 0,00 & 0,025 \\
Y Blocks & 3,50 & 2,46 & 0,28 & 0,05 & 0,014 & 0,68 & 0,02 & 0,016 & 0,03 \\
\hline
\end{tabular}

\subsection{Test procedure on Y blocks}

The properties of grade 1050/750/07 were considered as target results by the authors. Four lots of $Y$ blocks were submitted to four austempering times, varying from 1.5 to 3 hours, to reach the desired properties and evaluate traction and hardness of a component made of ADI. Samples were extracted from Y blocks according to standard [12] and all testings followed standard recommendations and patterns $[13,14,15]$. The results are shown in table 3 .

Table 3: Y blocks tests

\begin{tabular}{|c|c|c|c|c|}
\hline & $\begin{array}{c}U T S \\
(M P a) \\
\end{array}$ & $\begin{array}{c}Y S \\
(M P a)\end{array}$ & $\begin{array}{c}\text { Elongation } \\
(\%)\end{array}$ & $\begin{array}{c}\text { Hardness } \\
(\text { HB })\end{array}$ \\
\hline $\mathbf{A}$ & \multicolumn{4}{|c|}{$1.5 \mathrm{~h}$} \\
\hline Y_11 & 1099 & 810 & 1,7 & 308 \\
\hline$Y_{-} 12$ & 1063 & 714 & 3,6 & 324 \\
\hline$Y \_21$ & 1119 & 769 & 5,1 & 324 \\
\hline Y_22 & 1090 & 693 & 4,6 & 329 \\
\hline B & \multicolumn{4}{|c|}{$2.0 \mathrm{~h}$} \\
\hline Y_31 & 1175 & 807 & 3,2 & 303 \\
\hline Y_32 & 1112 & 760 & 5,9 & 343 \\
\hline$Y_{-}^{-} 41$ & 1197 & 848 & 4,1 & 308 \\
\hline Y_42 & 1113 & 762 & 4,3 & 321 \\
\hline $\mathbf{C}$ & \multicolumn{4}{|c|}{$2.5 \mathrm{~h}$} \\
\hline Y_51 & 1018 & 711 & 9,7 & 324 \\
\hline$Y_{-} 52$ & 1156 & 827 & 9,2 & 318 \\
\hline Y_61 & 1055 & 749 & 8,1 & 324 \\
\hline Y_62 & 1181 & 850 & 8,0 & 318 \\
\hline$\overline{\mathbf{D}}$ & \multicolumn{4}{|c|}{ 3.0h } \\
\hline Y_71 & 1016 & 679 & 10,1 & 329 \\
\hline$Y_{-} 72$ & 1007 & 669 & 10,2 & 321 \\
\hline Y_81 & 1041 & 726 & 11,4 & 308 \\
\hline Y_82 & 1101 & 771 & 9,6 & 313 \\
\hline
\end{tabular}


From these results, lot $\mathrm{B}$ was chosen with closer properties to target grade 1050/750/07, and the ideal heat treatment parameters were finally established and could be applied to connecting rod prototypes: austenitization at $910^{\circ} \mathrm{C}$ for 1.5 hours, transportation time of 2 seconds and austempering at $350^{\circ} \mathrm{C}$ for 2 hours.

\subsection{Casting and machining of connecting rods}

The chosen product as application of this project was a forged connecting rod already available in market, called " $\mathrm{C} 1$ " in this paper. The geometry and dimensional specifications were kept the same, regardless few adaptations for the casting process, such as new dimension of stock material and draft angle changes). The new casted connecting rod was named "C2" and is shown in Figure 3 below.

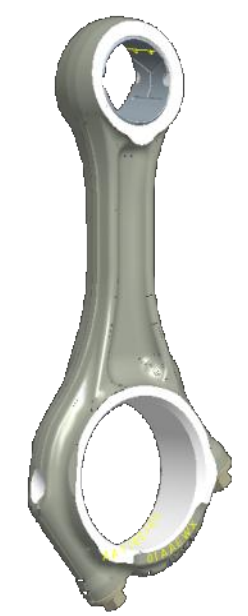

Figure 3: Connecting Rod "C2"

To evaluate the process influence on components performance, two lots of connecting rod prototypes were manufactured and treated in two different foundries following the chemical composition and the heat treatment parameters previously established (Tables 2 and 3). To preserve the confidentiality of the suppliers, the first foundry is called "F1" and the second foundry "F2". Machining of 500 casted connecting rods was made internally, on current machining line, respecting tolerances and dimensional parameters.

\subsection{Connecting rod tests}

The first test was performed on 50 random machined connecting rods to evaluate the hardness, according to ASTM standard [14]. On this step, the authors wanted to validate the direct influence of the austempering temperature variation the on hardness of ADI components, so 17 connecting rods were austempered at $310^{\circ} \mathrm{C}, 17$ were austempered at $350^{\circ} \mathrm{C}$ and 16 were austempered at $310^{\circ} \mathrm{C}$ for 2 hours, all with the austenitization at $910^{\circ} \mathrm{C}$ for 1.5 hours and transportation time of 2 seconds.

On the sequence, uniaxial traction test was performed to validate mechanical properties of the material and test samples were extracted from six connecting rods, following the recommendations of standard [13]. The first three connecting rods were casted by F1 and the other three were casted by F2. All connecting rods were 
thermally treated with austenitization at $910^{\circ} \mathrm{C}$ for 1.5 hours, transportation during 2 seconds and austempering at $350^{\circ} \mathrm{C}$ for 2 hours. The test was performed on Instron 2382 machine of $100 \mathrm{kN}$ load capacity with displacement control, 1,5 mm/min until yield followed by $3,0 \mathrm{~mm} / \mathrm{min}$ until fracture at $23^{\circ} \mathrm{C}$.

Metallographic analysis was then performed on the same six samples extracted from the connecting rod and previously submitted to the traction tests. The first analysis was to evaluate graphite count and form according to [14] while the second analysis evaluated the microstructure itself. A correlation of microstructure with traction test results was further discussed. The preparation of samples also followed the recommendations of standard [14] for cast irons.

Finally, fatigue tests were performed on 15 connecting rods of each supplier and were later compared. These tests were made internally on a traction-compression machine with alternated load of approximately 30 kips, stress ratio of $\mathrm{R}=-3$ (minimum over maximum stresses) and followed ThyssenKrupp's quality department standards. The failure mode and fracture positions were evaluated and later crack analysis was performed with visual and SEM inspection.

\section{RESULTS AND DISCUSSION}

On the next topics, results of tests performed on connecting rods are presented followed by a brief discussion. Each of them had specific specimens and parameter variations, so the results are presented separately according to test type.

\subsection{Hardness test}

The results of hardness tests on 50 connecting rods are presented on Table 4 below. These results corroborate with the theory that increase of austempering temperature directly impacts the hardness.

When austempering temperatures increase, more austenite with high carbon content is present and the number of ferrite particles is smaller because they become bigger and more elongated. It is known that austenite particles are softer than ferrite. Also, at higher temperatures, there are almost none dispersed carbides along the structure, which would have given more hardness to the material.

Table 4: Hardness

\begin{tabular}{l|cc}
\hline & Austempering temperature $\left({ }^{\circ} \boldsymbol{C}\right)$ & Hardness $(\boldsymbol{H B})$ \\
\hline $\mathbf{1 7}$ & 310 & 395 \\
$\mathbf{1 7}$ & 350 & 343 \\
$\mathbf{1 6}$ & 370 & 298 \\
\hline
\end{tabular}

For lower austempering temperatures, hardness is increased but, as a consequence, fracture toughness is damaged, mainly due to unstable austenite transformation into martensite after impact or deformation. Fracture mode for lower austempering temperatures samples should be brittle or cleavage. 


\subsection{Traction test}

Results of traction tests on the samples are shown in Table 5 below. 1A, 1B and 1C are the samples extracted from three connecting rods casted and treated by F1, while $2 \mathrm{~A}, 2 \mathrm{~B}$ and $2 \mathrm{C}$ are the samples of three connecting rods casted and treated by F2.

Table 5: Traction

\begin{tabular}{c|ccc}
\hline Sample & UTS (MPa) & YS (MPa) & Elongation (\%) \\
\hline 1A & 1079 & 699 & 7.7 \\
1B & 1122 & 841 & 15.9 \\
1C & 1148 & 865 & 15.9 \\
2A & 1085 & 849 & 12.6 \\
2B & 1097 & 860 & 13.6 \\
2C & 1114 & 865 & 14.8 \\
\hline
\end{tabular}

Samples 1B and 1C from F1 attended the specifications of the chosen ADI grade (1050/750/07 showed on Table 1) with tensile limits higher than $1120 \mathrm{MPa}$ and elongations above $15 \%$. Sample $1 \mathrm{~A}$, on the other hand, presented a slight smaller tensile limit and a much smaller elongation due to bigger strain hardening. This behavior is not usual on ausferritic/austenitic materials and further analysis on the microstructure of this sample must be done.

Samples from F2 also attended the ADI grade specifications. Yield stress limits of these specimens were kept around $850 \mathrm{MPa}(100 \mathrm{MPa}$ above the requirement) and the ultimate tensile limit were kept around $1080 \mathrm{MPa}$ (30 MPa above the minimum specified). Also, elongation values were far above the minimum required. Thus, casting process of F2 supplier provides more uniform samples, regarding mechanical behavior and a metallographic analysis should be done for validation.

\subsection{Graphite analysis}

The graphite analysis was performed on first on F1 samples and then on three F2 samples. Figure 4 shows the micrograph of samples $1 \mathrm{~A}(\mathrm{a}), 1 \mathrm{C}(\mathrm{b})$ and $2 \mathrm{~A}$ (c). The graphite count for $1 \mathrm{~A}$ was 139 nodules $/ \mathrm{mm}^{2}, 168$ nodules $/ \mathrm{mm}^{2}$ for $1 \mathrm{C}$ and 129 nodules $/ \mathrm{mm}^{2}$ for $2 \mathrm{~A}$.

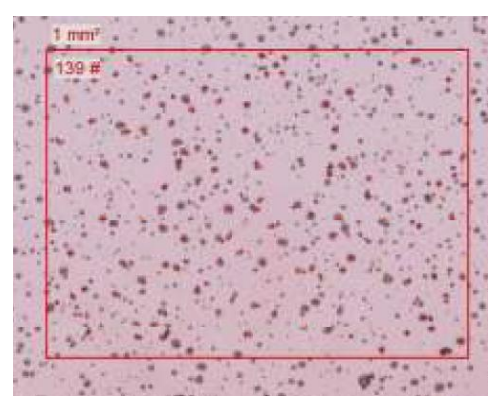

(a)

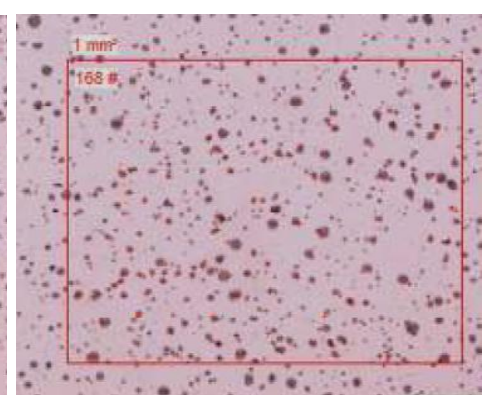

(b)

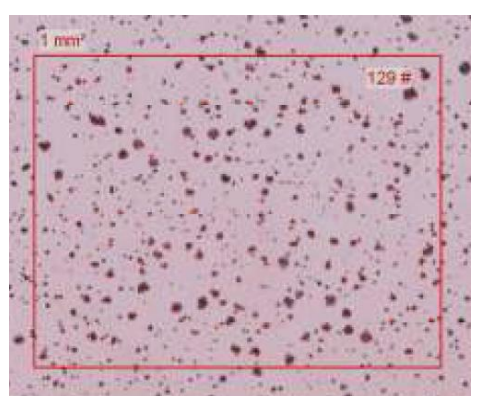

(c)

Figure 4: Graphite count for sample 1A (a), 1C (b) and 2A (c).

Sample 1A presented a different nodule count than other samples obtained by the same supplier, showing that the casting process of supplier F1 is not stable regarding 
inoculation. It is known that nodule count and graphite nodularization are great influences on the ductility of ADI components [9] and this was verified after analysis of F1 samples: 1C had more nodules and showed higher elongation values. F2 samples showed regular and stable nodule count among the samples inside the literature [8] recommendations - but lower then F1 samples. All samples presented good and expected graphite sizes and formats, equivalent to types I and II of ASTM [14].

\subsection{Metallographic analysis}

Metallographic analyses were performed on all six samples, but figure 5 only shows the microstructure analysis of samples 1A (a), 1C (b) and 2A (c) for comparison and discussion. Sample 1A presented fine ferrite microstructure with dark undefined structures and graphite nodules with low nodularization. This sample had undesired mechanical behavior, probably due to the irregular distribution of graphite along the structure and high amount of structures different from the expected ADI ausferritic matrix.

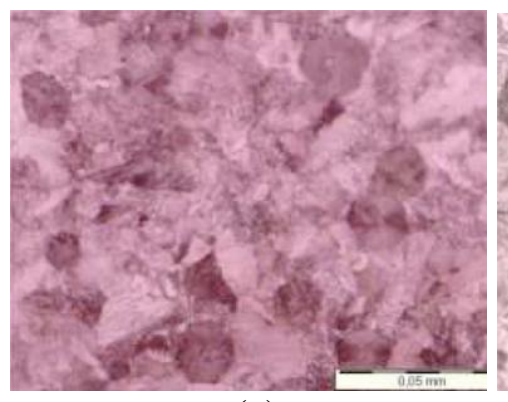

(a)

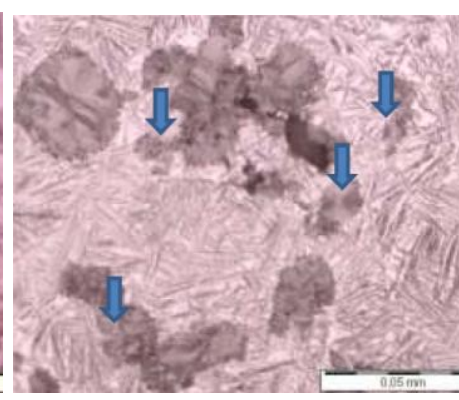

(b)

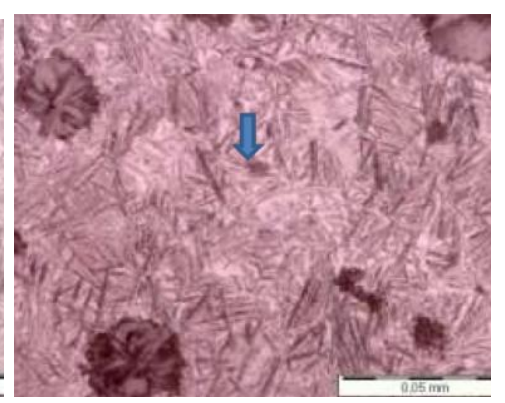

(c)

Figure 5: Micrography of samples 1A (a), 1C (b) and 2A (c)

Sample 1C showed ausferritic microstructure on approximately $70 \%$ of the total area with $15 \%$ of fine, small and intercellular retained austenite and $15 \%$ of graphite nodules. There are some unidentified dark structures along and between the graphite nodules, especially around the least spherical ones.

All samples from F2 supplier showed similar microstructure to sample 2A and this sample, specifically, showed ausferritic matrix with isolated needles of ferrite and fine retained austenite dispersed in intercellular positions. There are some vestiges of unfamiliar structures along the ausferrite.

The unknown structures are marked on figure 5 with arrows. On sample 1C they presented composition and similar characteristics to pearlite, showing that, maybe, quenching and austempering were inefficient and carbon could not dissolve properly from the graphite into austenite. Pearlite has totally different properties, mischaracterizing the expected mechanical behavior of these samples. The unknown structure on sample 2A appears to be hard carbide trapped between austenite structures. Carbides have a direct influence on elongation and hardness of the samples and can be originated from segregation of alloy elements. 


\subsection{Fatigue test}

The following two figures present the results for F1 connecting rods. Figure 6 shows the numerical results in kips ( 1 kip is equivalent to $6.9 \mathrm{MPa}$ ) on table format and failure position pointed on a schematic connecting rod on the right side. Figure 7 shows its respective $\mathrm{SxN}$ curve.

\begin{tabular}{|c|c|c|c|c|c|c|}
\hline $\begin{array}{c}\text { SAMPLE } \\
\text { ID\# }\end{array}$ & $\begin{array}{c}\text { Alternating } \\
\text { Load (kips) }\end{array}$ & $\begin{array}{c}\text { Mean Load } \\
\text { (kips) }\end{array}$ & $\begin{array}{c}\text { Max Load } \\
\text { (kips) }\end{array}$ & $\begin{array}{c}\text { Min Load } \\
\text { (kips) }\end{array}$ & \# of cycles & $\begin{array}{c}\text { Failure } \\
\text { Location }\end{array}$ \\
\hline 15 & 34,825 & $-16,475$ & 18,350 & $-51,300$ & 1.609 .612 & $\mathrm{~A}$ \\
\hline 14 & 33,807 & $-15,993$ & 17,814 & $-49,800$ & 3.047 .087 & $\mathrm{E}$ \\
\hline 13 & 32,788 & $-15,512$ & 17,276 & $-48,300$ & 1.064 .125 & $\mathrm{~F}$ \\
\hline 12 & 31,770 & $-15,030$ & 16,740 & $-46,800$ & 1.542 .121 & $\mathrm{~B} / \mathrm{C}$ \\
\hline 07 & 30,752 & $-14,548$ & 16,204 & $-45,300$ & 10.000 .000 & OK \\
\hline 08 & 31,770 & $-15,030$ & 16,740 & $-46,800$ & 931.631 & $\mathrm{~A}$ \\
\hline 11 & 30,752 & $-14,548$ & 16,204 & $-45,300$ & 4.668 .912 & $\mathrm{~A}$ \\
\hline 05 & 29,734 & $-14,066$ & 15,668 & $-43,800$ & 10.000 .000 & OK \\
\hline 10 & 30,752 & $-14,548$ & 16,204 & $-45,300$ & 7.872 .635 & $\mathrm{~F}$ \\
\hline 1 & 29,734 & $-14,066$ & 15,668 & $-43,800$ & 10.000 .000 & OK \\
\hline 4 & 30,752 & $-14,548$ & 16,204 & $-45,300$ & 2.193 .537 & $\mathrm{~B} / \mathrm{C}$ \\
\hline 9 & 29,734 & $-14,066$ & 15,668 & $-43,800$ & 9.225 .926 & $\mathrm{D}$ \\
\hline 3 & 28,715 & $-13,585$ & 15,130 & $-42,300$ & 10.000 .000 & OK \\
\hline 2 & 29,734 & $-14,066$ & 15,668 & $-43,800$ & 4.185 .160 & $\mathrm{~F}$ \\
\hline 6 & 28,715 & $-13,585$ & 15,130 & $-42,300$ & 1.441 .615 & $\mathrm{~B} / \mathrm{C}$ \\
\hline
\end{tabular}

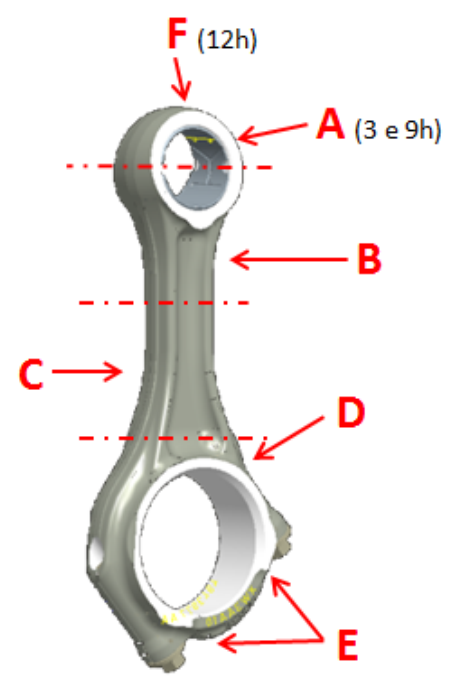

Figure 6: Fatigue test results for F1 connecting rods

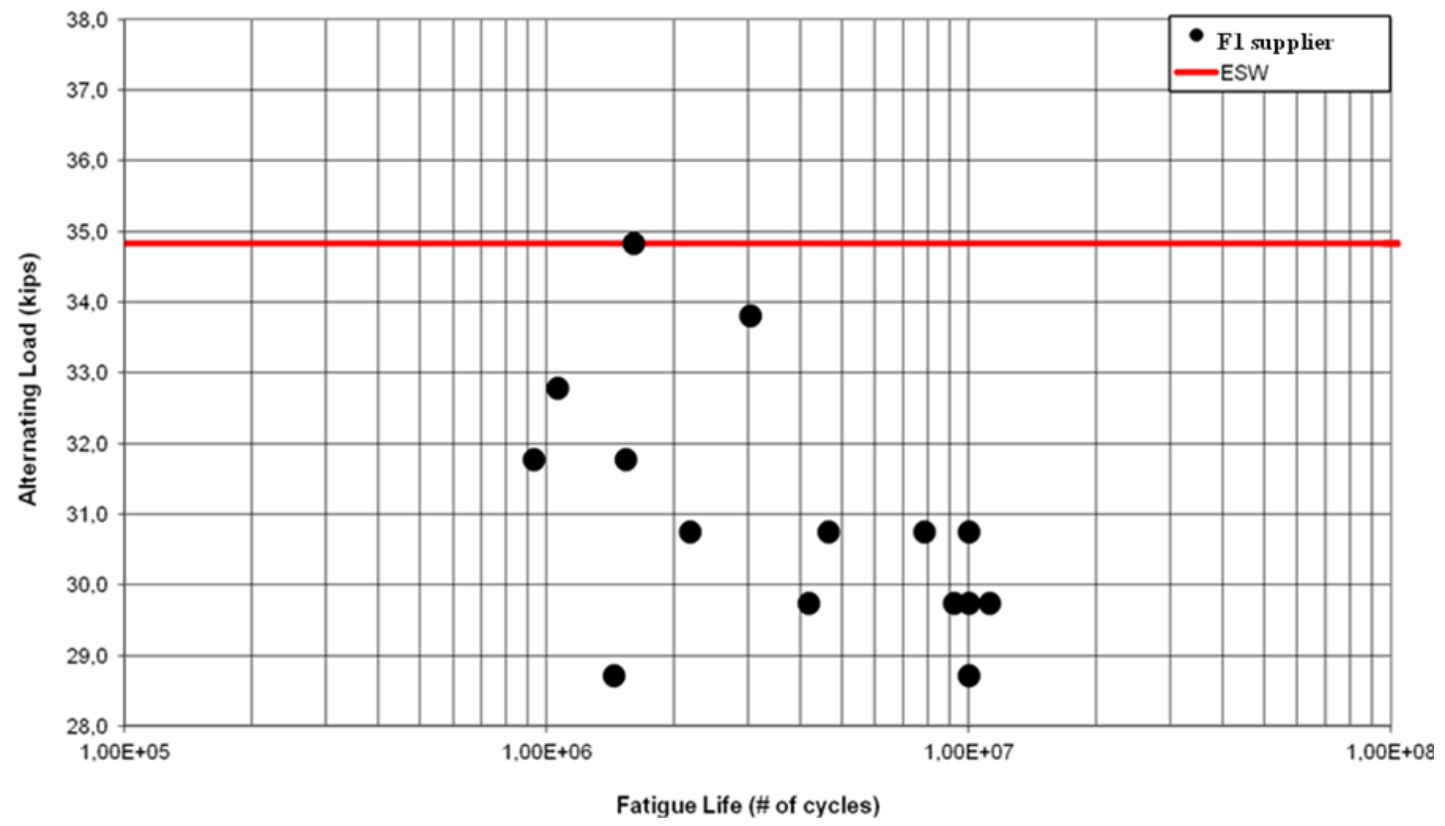

Figure 7: $\mathrm{SxN}$ curve for $\mathrm{F} 1$ connecting rods

Of the 15 tested connecting rods, only four reached the 10 million cycle life limit. The load used as a starter (ESW) was 34.825 kips and as failure was observed in this condition, load was gradually lowered until 10 million cycles are reached. Sample number 07 reached fatigue life with 30.752 kips and load was once again raised to 31.770 kips. Still, samples presented failures and load was lowered and the other three samples reached infinite fatigue life with loads around 29 kips. 
F1 connecting rods presented a fatigue limit inferior to the ESW limit; in other words, it was inferior then the standard limit for this component. Also, it was way inferior than current forged connecting rod limit (37 kips). Considering that these connecting rods were tested without bushing and with a piston pin assembled with interference, superior results were expected. The lack of bushing contributed to failures occurring on position A, because it normally acts as a load absorber for the small eye.

Most failures on F1 connecting rods were observed on the small end (positions A and F) and this is not coherent to connecting rods typical failure modes. Although the small eye suffers highest loads from combustion and piston pin accommodation, failure should occur in this region only if a stress concentration is located there. Cracks occurring on positions B, C and D located on the shank of the component are very usual, especially on $\mathrm{B}$ and $\mathrm{D}$ due to the transition radius. Failures on position $\mathrm{C}$ are only usual on connecting rods with poor dimensioning or with material defects.

The following two figures present the results for F2 connecting rods. Figure 8 shows the numerical results on table format and failure position pointed on a schematic connecting rod on the right side. Figure 9 shows its respective SxN curve. F2 samples were submitted to the same experimental procedure of F1 samples, this way the results could be fairly compared. Sample number 15 could not be tested properly due to torque problems on the machine, so its results are not presented here.

Once again, from the 15 tested connecting rods, only four reached the fatigue life limit of 10 million cycles. The same ESW Limit of 34.825 kips was used as a starter, load was lowered gradually and infinite fatigue life was only achieved around 25 kips, approximately 4 kips lower than F1.

\begin{tabular}{|c|c|c|c|c|c|c|}
\hline $\begin{array}{c}\text { SAMPLE } \\
\text { ID\# }\end{array}$ & $\begin{array}{c}\text { Alternating } \\
\text { Load (kips) }\end{array}$ & $\begin{array}{c}\text { Mean Load } \\
\text { (kips) }\end{array}$ & $\begin{array}{c}\text { Max Load } \\
\text { (kips) }\end{array}$ & $\begin{array}{c}\text { Min Load } \\
\text { (kips) }\end{array}$ & \# of cycles & $\begin{array}{c}\text { Failure } \\
\text { Location }\end{array}$ \\
\hline $\mathbf{1 3}$ & 34,825 & $-16,475$ & 18,350 & $-51,300$ & 485.755 & $\mathrm{C}$ \\
\hline $\mathbf{1 4}$ & 33,807 & $-15,993$ & 17,814 & $-49,800$ & 661.739 & $\mathrm{C}$ \\
\hline $\mathbf{1 2}$ & 32,788 & $-15,512$ & 17,276 & $-48,300$ & 1.216 .711 & $\mathrm{~B}$ \\
\hline $\mathbf{5}$ & 31,770 & $-15,030$ & 16,740 & $-46,800$ & 3.668 .523 & $\mathrm{~B}$ \\
\hline $\mathbf{1 1}$ & 30,752 & $-14,548$ & 16,204 & $-45,300$ & 3.453 .398 & $\mathrm{C}$ \\
\hline $\mathbf{8}$ & 29,734 & $-14,066$ & 15,668 & $-43,800$ & 736.285 & $\mathrm{C}$ \\
\hline $\mathbf{4}$ & 28,715 & $-13,585$ & 15,130 & $-42,300$ & 1.623 .588 & $\mathrm{C}$ \\
\hline $\mathbf{2}$ & 25,661 & $-12,139$ & 13,522 & $-37,800$ & 10.000 .000 & OK \\
\hline $\mathbf{1}$ & 26,679 & $-12,621$ & 14,058 & $-39,300$ & 10.000 .000 & OK \\
\hline 3 & 27,697 & $-13,103$ & 14,594 & $-40,800$ & 712.881 & $\mathrm{~B}$ \\
\hline $\mathbf{6}$ & 26,679 & $-12,621$ & 14,058 & $-39,300$ & 10.000 .000 & $\mathrm{OK}$ \\
\hline $\mathbf{1 0}$ & 27,697 & $-13,103$ & 14,594 & $-40,800$ & 10.000 .000 & OK \\
\hline $\mathbf{9}$ & 28,715 & $-13,585$ & 15,130 & $-42,300$ & 5.890 .359 & $\mathrm{~A}$ \\
\hline 7 & 27,697 & $-13,103$ & 14,594 & $-40,800$ & 1.032 .287 & B/C \\
\hline 15 & \multicolumn{7}{|c|}{ Torque problem } \\
\hline
\end{tabular}

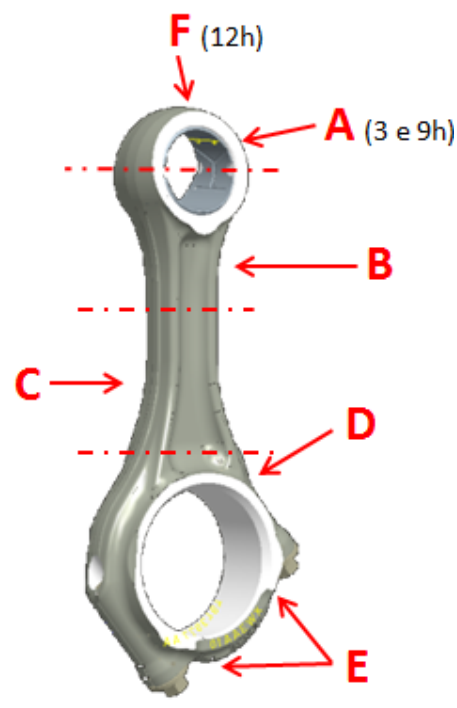

Figure 8: Fatigue test results for F2 connecting rods 


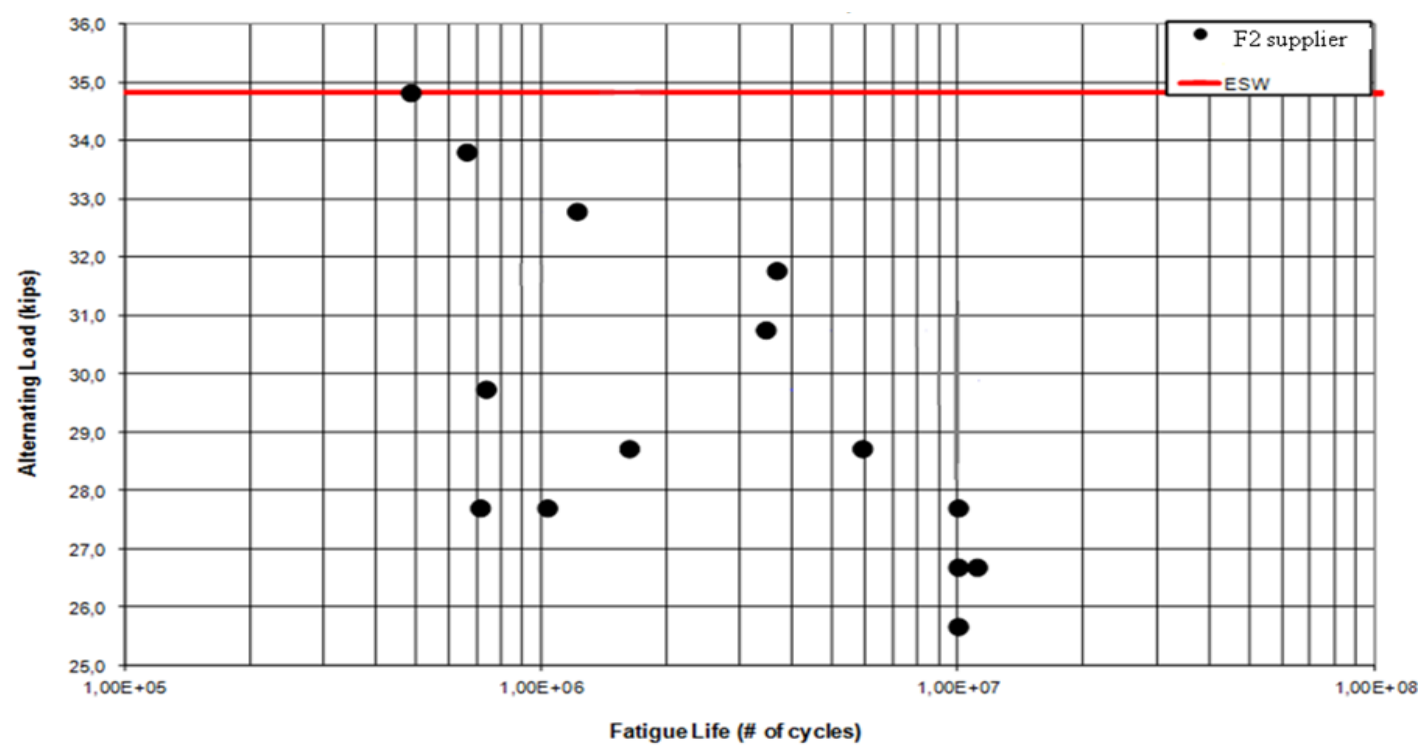

Figure 9: SxN curve for F2 connecting rods

Differently from F1, F2 samples presented most of the failure modes on the shank region, especially on position $\mathrm{B}$, which is expected for this type of component. But, cracking on position $\mathrm{C}$ is probably originated from stress concentrators coming from material and process defects. Failure position A occurred probably due to the bushing absence, which normally absorbs this kind of loading.

Fractography was performed on failed samples to find out the real causes and origins of the cracks and to validate the discussion made in this topic. The results will be presented further on this paper.

\subsection{Crack analysis}

Figure 10 shows the cross section picture of sample 4 of the F1 batch (a) and the SEM image (b). This sample presented failure on the shank and the analyzed points are numbered from 0 to 5 on the picture.

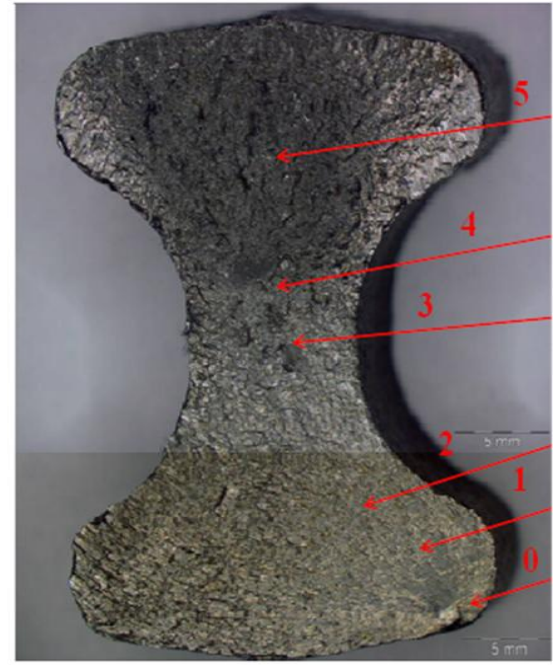

(a)

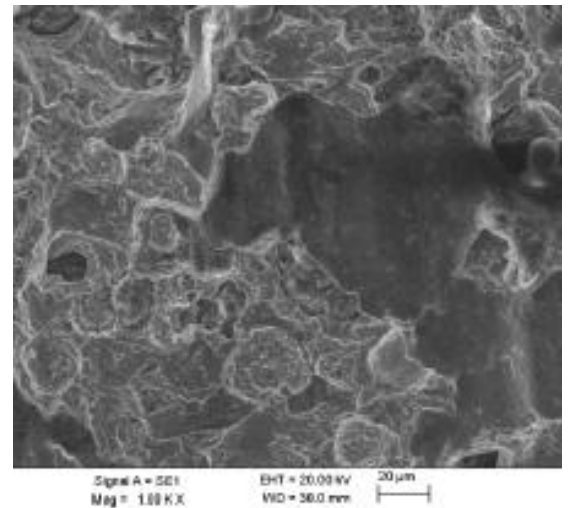

(b)

Figure 10: Cross section of sample \#4 (a) and SEM analysis (b). 
Point 0 corresponds to crack beginning, where lack of filling and inclusions can be observed. Fatigue crack propagated like beach sand waves as can be seen on points 1 and 2. Crack follows the graphite nodules and defects and the beach sand waves stop on the middle of the shank, where the material is more resistant. In this area, fracture becomes less plain, with relief variations and some evidence of semi-cleavage. Crack continues through the material (points 3 and 4) and on the superior half of the cross section, practically all area presents catastrophic failure. Its morphology consists on loose graphite nodules, plastic deformation and cleavage (point 5).

Figure 11 shows the cross section picture of sample 8 of the F1 batch (a) and the SEM image (b). This sample presented failure on the small eye and the analyzed points are numbered from 0 to 5 .

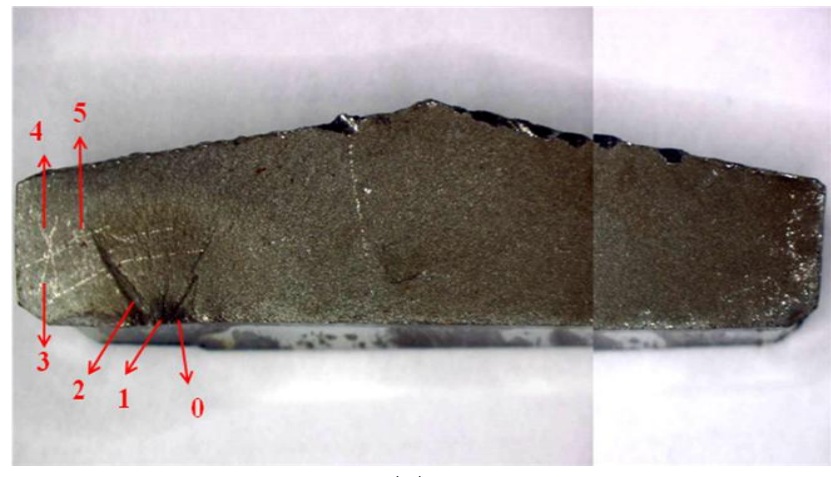

(a)

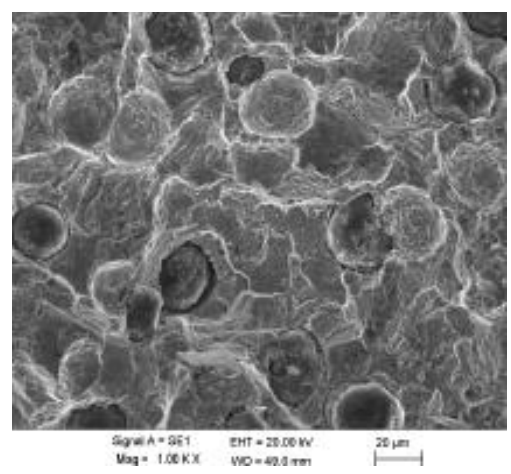

(b)

Figure 11: Cross section of sample \#8 (a) and SEM analysis (b).

Crack begins on the inferior left side of the section, on several casting defects and superficial irregularities. It follows into different plans and paths (points 1 and 2) which further unite and produce a big wave centered in point 0 and edges on points 3,4 and 5. Approximately $25 \%$ of the area has fatigue cracking evidences and the SEM analysis showed graphite cohesion, plastic deformation and semi-cleavage.

Figure 12 shows the cross section pictures of samples 14 (a) and 10 (b) of F1 batch. These samples presented failure on the big and small eyes, respectively, not usual modes for connecting rods. Visual analysis proved that the main cause for crack initiation on these positions came from porosity originated from bad and uncontrolled casting process.

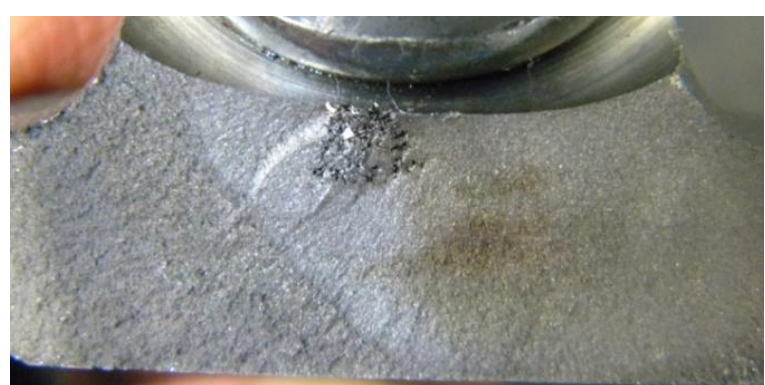

(a)

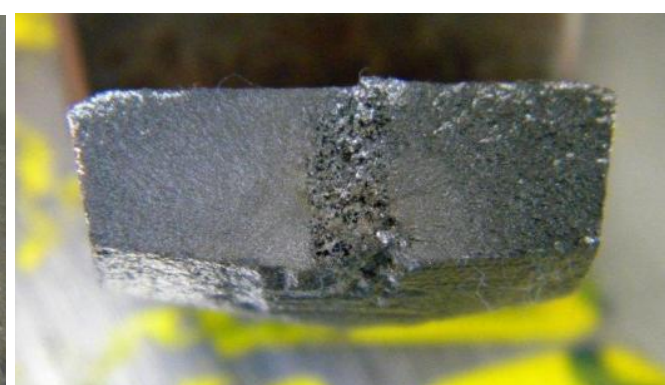

(b)

Figure 12: Cross section of samples \#14 (a) \#10 (b) 
Figure 13 shows the cross section pictures of sample 3 of the F2 batch (a) and the SEM image (b). This sample presented failure on the shank and the analyzed points are numbered from 0 to 8 .

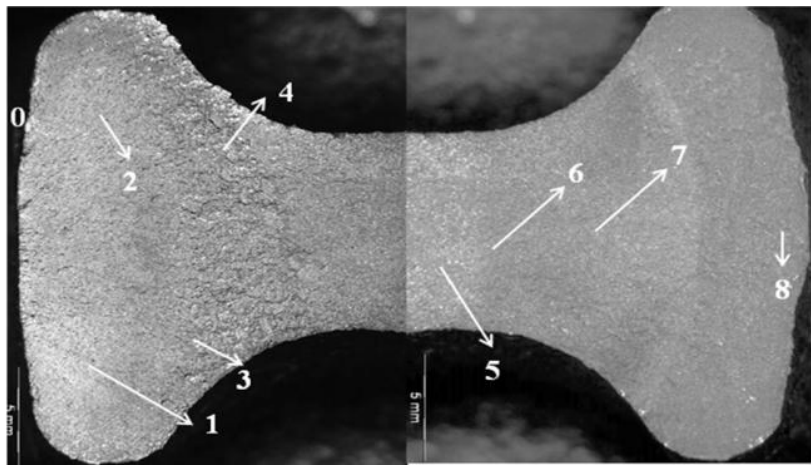

(a)

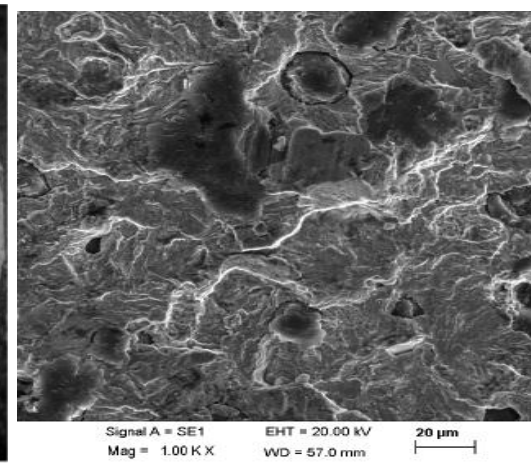

(b)

Figure 13: Cross section of sample \#3 (a) and SEM analysis (b)

Several types of fractures were verified, all initiated on the lateral flash line of the connecting rod on point 0 . Point 1 shows plain areas resulting from friction of the final fracture. In the SEM image above, separated graphite nodules can be observed. These characteristics mentioned are related to fatigue cracking evolving with high speed. Point 2 shows a more ductile fracture, moving to the inferior direction of the cross section, which brings the conclusion that fatigue cracking moved through this direction. Points 3 and 4 cracks lost the fatigue characteristics and the fracture mode from point 5 to point 8 are mainly ductile, with long and deformed micro cavities around retained austenite.

Figure 14 shows the cross section picture of sample 8 of the F2 batch (a) and the SEM image (b). This sample presented failure on the shank and the analyzed points are numbered from 0 to 8 .

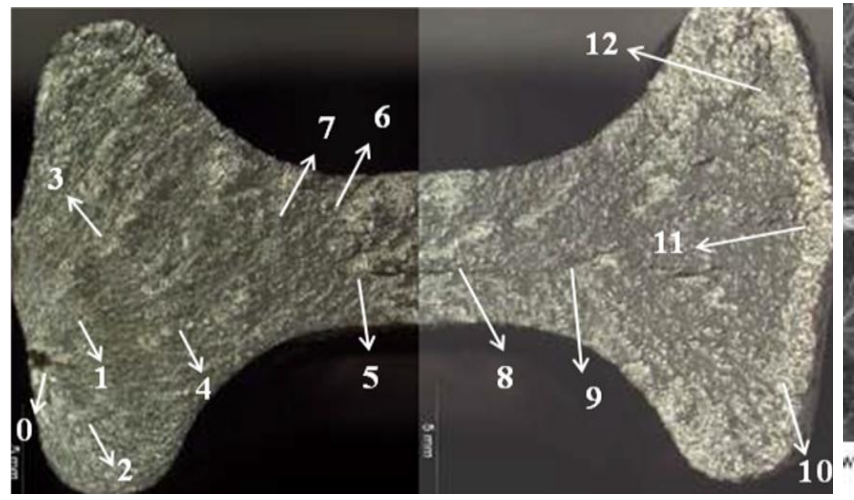

(a)

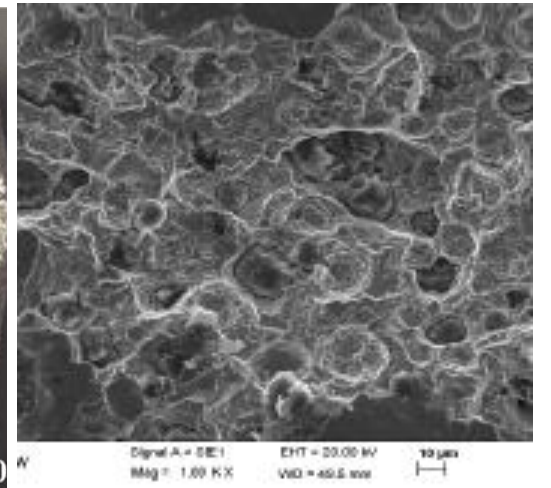

(b)

Figure 14: Cross section of sample \#8 (a) and SEM analysis (b)

Fracture initiated on a superficial irregularity on point 0 . On point 1 , really close to the fracture, matrix is broken, plain and the crack moved through different plans, without deformation. Points 2, 3 and 4, close to the fracture location showed similar morphologies with radial progression of the crack, but with some evidences of plastic deformation and loosen graphite nodules, as can be seen on SEM image. Fractures on 
points 8 to 12 show catastrophic characteristics, matrix has strong evidences of plastic deformations, with elongated micro cavities and loosen graphite nodules. Final rupture happened on $50 \%$ of the cross section area and on point 6 there is evidence of discontinuity of the matrix (micro shrinkage) coming from poor casting process.

\section{CONCLUSION}

As mechanical properties of ADI are strongly dependent on process parameters and microstructure characteristics, the relationship between foundry and heat treatment should be close. Chemical composition, inoculation degree and graphite morphology must be inside standard specifications to achieve the desired properties after heat treatment. Also, the austempering process must be controlled with correct temperature and time to reach the correct amount of ausferrite, without bainite or pearlite.

All samples presented unknown structures which directly influenced on the mechanical properties. Regarding fatigue, it was clear that ADI has inferior performance then forged steel. While ADI had an ESW Limit of 34 kips, connecting rods made of forged steel have 37 kips. Most fatigue cracking on the tested samples originated from material and superficial defects, inclusions, carbides or shrinkage.

Porosity was the main cause of cracks on the F1 connecting rods, which were not uniform regarding chemical composition and microstructure. Fractures were located on unusual positions, such as big and small ends. This proves that the casting process of foundry F1 was not satisfactory and generated stress concentrators that were visible to the naked eye.

F2, on the other hand, presented better control on its casting process, resulting on samples with better microstructures and few material defects (some shrinkage was observed). The irregularities in these samples were obtained after the casting process, especially on trimming and deburr steps, which left marks and defects on the lateral surface of the shank. The fatigue failure modes and positions on these samples were more consistent and the connecting rods presented more evidences of ductile fracture, although brittle fatigue cracking was predominant.

Austempered ductile iron is a very interesting material to be applied on engine components, especially due to its low density resulting on reduced weight and design flexibility, allowing the manufacturing of new and complex geometries. But, its limitations lay, mostly, on lower machinability, demanding special tooling, and fracture toughness then steel. Fatigue behavior of ADI also proved to be inferior and under engine operations, forged steel connecting rods are still the best and most competitive option. 
For further information, please contact:

Laura Elisa Bollini

Av. Alfried Krupp, 1050

Campo Limpo Paulista - SP 13231-900

Phone: (011) 4039-9504

E-mail: laura.bollini@thyssenkrupp.com

Almir Atoatte

Av. Alfried Krupp, 1050

Campo Limpo Paulista - SP 13231-900

Phone: (011) 4039-9795

E-mail: almir.atoatte@thyssenkrupp.com

\section{ACKNOWLEDGEMENTS}

For all the support during the project:

ThyssenKrupp Metalúrgica Campo Limpo Ltda.

Mr. Luis Galli - R\&D Manager.

Mr. Robson Cruz - R\&D Group Leader.

\section{REFERENCES}

[1] MASTROBUONO, R., Emissões de veículos a diesel - Evolução da tecnologia veicular. Seminário - Iveco, ANFAVEA, 2009.

[2] GUESSER, et al., Austempered Ductile Iron for Gears. SAE 36-0305. SAE International, 2012.

[3] BRANDENBERG, K.R., Successfully Machining Austempered Ductile Iron (ADI), Disponível em: http://appliedprocess.com/Custom/Document/GetFile/d7b2f031-cb0c-42adbdd8-6fd878c6bf72 Acesso em 30/04/2015.

[4] BALZER, M. E., Determinação da "janela de processo" de austêmpera de um ADI sem adição de elementos de liga através de ensaios mecânicos e metalográficos. 85f. Dissertação (Mestrado) - Universidade Federal de Santa Catarina, Florianópolis, 2013.

[5] KOVACS, B.V., Development of austempered ductile iron (ADI) for automobile crankshafts. Journal of heat treatment. New York. Vol.5 p55-60, 1987.

[6] GUESSER, Wilson Luiz. Propriedades Mecânicas dos Ferros Fundidos. São Paulo: Blucher, 2009.

[7] RUNDMAN et al., The Microstructure and Mechanical Properties of Austempered Ductile Iron. Journal of heat treatment. New York. Vol.5 p 79-95, 1988.

[8] AMERICAN SOCIETY FOR TESTING AND MATERIALS. A897/A897M-06: Standard Specifications for Austempered Ductile Irons. Pennsylvania: ASTM International, 1990.

[9] SILVA, C., Influência do número de nódulos de grafita nas propriedades mecânicas do ferro fundido nodular austemperado. 2005. 116f. Dissertação (Mestrado) Universidade Federal de Minas Gerais, Belo Horizonte, 2005.

[10] PUTATUNDA et al., Development of austenite free ADI (austempered ductile iron). Materials Science and Engineering. A 435-436 p112-122, 2006.

[11] BRANDENBERG et al., An ADI Crankshaft Designed for High Performance in TVR's Tuscan Speed Six Sports Car. SAE 01-0408. SAE International, 2001. 
[12] AMERICAN SOCIETY FOR TESTING AND MATERIALS. ASTM536/A536-84: Standard Specification for Ductile Iron Casting. Pennsylvania: ASTM International, 2010. [13] AMERICAN SOCIETY FOR TESTING AND MATERIALS. E8/E8M-09: Standard Test Method for Tension Testing of Metallic Materials. Pennsylvania: ASTM International, 2010.

[14] AMERICAN SOCIETY FOR TESTING AND MATERIALS. ASTM247/A247-10: Standard Test Method for Evaluating the Microstructure of Graphite in Iron Casting. Pennsylvania: ASTM International, 2010.

[15] AMERICAN SOCIETY FOR TESTING AND MATERIALS. ASTM327/A327-91: Standard Test Method for Impact Testing of Cast Irons. Pennsylvania: ASTM International, 2010. 